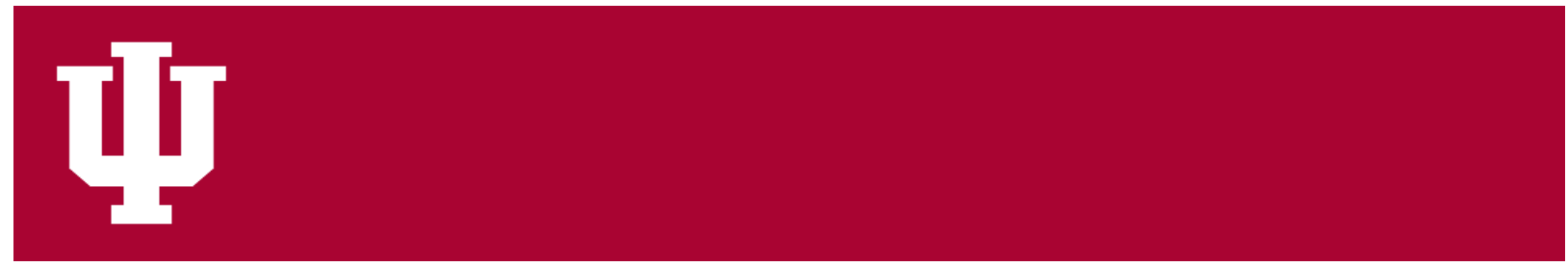

IUScholarWorks at Indiana University South Bend

\title{
Byzantine History and the Discourse of the Russian Political/Intellectual Underground
}

Shlapentokh, Dmitry

To cite this article: Shlapentokh, Dmitry. "Byzantine History and the Discourse of the Russian Political/Intellectual Underground.” Journal of Eurasian Studies, vol. 3, no. 1, Jan. 2012, pp. 80-91. ScienceDirect, doi:10.1016/j.euras.2011.10.009.

This document has been made available through IUScholarWorks repository, a service of the Indiana University Libraries. Copyrights on documents in IUScholarWorks are held by their respective rights holder(s). Contact iusw@indiana.edu for more information. 


\title{
Byzantine history and the discourse of the Russian political/intellectual underground
}

\author{
Dmitry Shlapentokh \\ Department of History, Indiana University South Bend, United States
}

\section{A R T I C L E I N F O}

\section{Article history:}

Received 24 March 2011

Accepted 11 July 2011

\begin{abstract}
A B S T R A C T
Historical subjects often seem to be unrelated to current political discourse still could be often politicized in present-day Russia. And Internet discussions on these historical subjects could well provide insight into the views of the various segments of the country's population. These Internet discussions become especially important sources when one tries to look into the minds of the Russian underground, those who have practically no legal outlet for presenting their views. For this reason, the movie The Death of the Byzantine Empire, shown in the very end of the Putin presidency, is especially important. The movie, created the Orthodox priest Tikhon Shevkunov, (presumably Putin's confessor) made clear references to contemporary Russia.

In the view of the producer, the Byzantine Empire was strong when it followed its autocratic tradition and was attached to Orthodoxy. The movie generated extensive discussions, including among those who belong to Russia's political and intellectual fringe. Quite a few of them were neo-pagans; for them, Christianity, including Orthodox Christianity, was Russia's curse. For them, it was an Asian creed foreign to Aryan Russians. The fact that it was accepted by Russians implied that Russians had been subjugated by an alien, Asiatic, force. Many of these neo-pagans were quite pessimistic in regard to the country's future; and, indeed, their response indicates the deep alienation of quite a few Russians, which hardly bodes well for the country's future.
\end{abstract}

Copyright @ $\odot$ 2011, Asia-Pacific Research Center, Hanyang University. Produced and distributed by Elsevier Limited. All rights reserved.
Historical subjects that seem unrelated to current discourse are still often politicized in present-day Russia. Internet discussions on these subjects can provide insight into the views of the various segments of the population. These discussions become especially important when one tries to look into the minds of the Russian underground, those who have practically no legal outlet for presenting

E-mail address: dshlapen@iusb.edu.

$$
\text { Produced and distributed by Elsevier Ltd. }
$$

their views. The movie The Death of the Byzantine Empire, shown at the very end of the Putin presidency, is especially important. Created by Orthodox priest Tikhon Shevkunov (presumably Putin's confessor), it made clear references to contemporary Russia. In the view of the producer, the Byzantine Empire was strong when it followed its autocratic tradition and was attached to Orthodoxy.

The movie generated extensive discussions, including among those who belong to Russia's political and intellectual fringe. Quite a few were neo-pagans; for them, Christianity was a curse, an Asian creed foreign to Aryan Russians. That it was accepted by Russians implied that Russians had been subjugated by an alien, Asiatic, force. 
Many of these neo-pagans were quite pessimistic in regard to the country's future; indeed, their response indicates the deep alienation of quite a few Russians, which hardly bodes well for the country's future.

In 2008, at the very end of Putin's tenure, the movie Death of the Byzantine Empire was shown on Russian TV. The philosophy of the movie is clear. The Byzantine Empire was great when it followed its Orthodoxy and authoritarian corporatism. The influence of the West rotted the imperial political/ideological core and weakened the empire. It received its first blow in 1204, when Western crusaders took Constantinople, and the second, almost 250 years later, when it fell under the onslaught of the Ottoman Turks. The comparison with present-day Russia is transparent, and the message is clear: Westernization or alliance with the West would lead Russia to the same downfall as the Byzantines several centuries before.

Tikhon Shevkunov, the priest who created the movie, was, according to rumors, Putin's confessor; and the assumption is that his views are the same as those of considerable numbers of the Russian elite. This sort of assumption made the movie and its ideas popular among many Russian TV viewers, leading to intensive polemics on the Internet-the major source of uncensored Russian opinions today.

Some intellectuals' constructions have presented the views of the most active part of the Russian populace, and, one might assume, a considerable segment of the Russian elite. Of these, some have supported Tikhon's premises and see in the West the source of all Russian evil. Others have an opposite view and regard the major threat as from the East, mostly the Muslim world. With all their differences, these two groups mostly see chances for Russia to survive and prosper in the present political and spatial framework of the country, broadly defined.

There was also a layer of opinion from quite a different group, those who were disenfranchised and deeply alienated from all aspects of the country's life. And they have their particular views of Orthodoxy and its role in society-the central point of the movie. Some could be regarded as a new edition of "Old Believers." In their view, the present Orthodox Church drives Russians away not only from the West but from the country's true Christian tradition. The return to true Orthodoxy would require drastic changes, which are unlikely to be implemented because the country has no future in the long run. For others, a return to true Orthodoxy, to true Russia, would require a return to the pre-Mongolian times of Kievan Rus'.

For yet others, in particular, neo-pagans, Orthodoxy is just an oppressive and foreign creed, an integral part of an oppressive system that has tortured Russia for centuries. For them, the Golden Age was not in pre-Mongolian Rus' but in the pre-Christian pagan past. Return to this era is seen as impossible; this has led them to the feeling that, regardless of any changes, Russia is as doomed as the Byzantine Empire.

\section{Diomid and the crisis of the Orthodox Church}

A deep pessimism in regard to Russia's future is related by some of the movie viewers with their critical views of the Russian Orthodox Church. Indeed, the Orthodox Church in present-day Russia has experienced serious troubles. A manifestation of the depth of the crisis is the case of Bishop Diomid, who rebelled against the entire church hierarchy. He accused them of immorality, caring about nothing except personal enrichment and allowing the rich to rob the poor (Credo.ru, 2008a; Vermisheva, 2007). In his view, both the Moscow (Moskovskaia Patriarkhia) and Constantinople Patriarchs have betrayed Orthodoxy and are ready to surrender it to Catholicism (Dukh khristianina, 2008). He also attacked the Kremlin, proclaiming that the present regime does not act in the Russian people's interests (Gazeta.ru, 2007). Finally, he declared Patriarch Aleksei II of Moscow and all Russia anathema.

Diomid's case became a major event in Russian quasireligious and quasi-political life at the end of Putin's presidency. A popular explanation was that he was actually a creation of the Kremlin elite. It connects Diomid with intrigue at the very top of the elite and, according to some pundits, provides clues about the elite's plans for the future. This general theoretical framework has led to a variety of more precise explanations.

Some believed that Diomid's actions reflect the political struggle in the Church and the Russian elite in general, who are locked in a mortal struggle (Credu.ru, 2008b). Some even believed Diomid is the creation of members of the elite who want to install a monarchy if the present regime fails (Razdumyvaiushchii, 2008). In this interpretation, he is a product of "Jewish power" in the Kremlin, which wants to create a split among Russian Orthodox people as the only way to survive, and possibly to install a puppet monarchy. The point is that the ideological brainwashers of the regime and the Orthodox Church could not really protect the regime and lead people away from revolt.

Many Orthodox Russians hate the present Moscow Patriarch. They assume he actually leads the "kikes' church" (zhidovstvuiushchaia tserkov) (Kak raskruchivaetsia el'tsinskii stsenarii, 2007: 3). Church leaders with such a reputation could hardly lead the masses away from harsh dealing with the current elite, and here Diomid might be of great help. Many people would support him, and he would help organize them in a sort of detachment of the Orthodox oprichniki, even a sort of Orthodox hunveibins to buttress the regime and possibly help create a puppet monarchy (a reference to the "Red Guards" in China who engaged in pogrom-type violence during the Cultural Revolution).

Other observers saw the rise of Diomid as the result of the popularity of his views among average people. His enemies try to discredit him because he shows the core nature of the present regime. During Soviet rule, the authorities preached atheism, but their moral code was quite similar to the Christian one. The present regime actually preaches Satanism (Dobychin, 2008), and Diomid saw this clearly. Still, it would be wrong to see Diomid's conflict with the church as a personal grudge. His actions were caused by a variety of reasons, the major one the deep disenchantment of a considerable number of average Russians with the Russian Orthodox Church and the entire political establishment. This could be proved by the vicious attacks on Diomid by both Kremlin and Church authorities. Both wish to remove him. He is accused of stealing church 
money (Credo.ru, 2008c), which could lead to his imprisonment. And there seem to be other plans as well. Diomid stated his enemies want to put him in prison or in a madhouse (Credo.ru, 2008d,e).

The authorities' fears of Diomid's influence are quite justified, for he has received broad support. All those who support him state that he is an extraordinary person, quite different from those in the Russian Orthodox hierarchy. They point out that while Orthodoxy's hierarchy and, implicitly, the Kremlin's, try to present Diomid as insane and isolated, this is not the case. He should not be dismissed as an insane character whose concerns/views have nothing to do with those of Russian society.

One reason Diomid's views have resonated among at least some members of Russian society, is the apparent inability of the Orthodox Church to provide moral guidance or improve the morals of Russian society, as was expected by many at the beginning of the Gorbachev era. Diomid's supporters state that when, in 1988, Gorbachev legitimized the thousand-year celebration of the Baptism of Russia, it caused a real sensation. People believed Russia was on the eve of a religious renaissance. The turn to religion was seen by quite a few Russians as not only a return to Russia's historical roots, to the beliefs of their forefathers, but also as a moral cleansing, a way to kindness, compassion, and spirituality. At that time, when attacks against the Soviet regime were constantly increasing, the Soviet era was seen as the embodiment of immorality of all types. There were high hopes for moral regeneration.

This did not happen. It is true that now two-thirds of the Russian population regard themselves as Orthodox, but only a few attend church on a regular basis (Arutunyan, 2007). Moreover, religious ethics hardly play any role in people's lives. "It was not the maxim of religion but gas and money that actually became Russia's national ideal" (Bolotova and Kipiani, 2008). The Orthodox Church as an institution soon lost the image of moral anchor of society. It quickly became integrated in the operations of the state, returning to the role it played in prerevolutionary Russia. Moreover, one could assume it continued to be a part of the state machinery as it had since the late Stalinist era. Its return to the forefront as the major ideological institution/prop of the regime was quite natural when Communist ideology-a quasi-religion-disappeared from public sight. As part of the bureaucracy of the state, the Church rendered complete support to state policies-as, of course, it had in the past. It did little to ameliorate the gaping social divisions: luxurious life of the few and abject poverty of many. In its complete support of the ruling elite, it actually blessed the exploitation of the majority by the elite, whose riches hardly benefited Russian society as a whole. Furthermore, the Church was infected by all the ills of post-Soviet society. There was a huge gap in living standards between the Church hierarchy and the average priest. Church bureaucracy, following the footsteps of the state bureaucracy, engaged in corruption, shady deals, and similar actions where filthy lucre was the only goal. It is not surprising that the moral authority of the Church became as questionable as that of the Party hierarchy, and ideologists in the late Soviet era.
The Russian Orthodox Church, with its ecumenical and implicitly pro-Western orientation, should be approached in the context of these problems. It is true that the Church had fought against proselytization by Western especially churches. But the conflict was not a case of conflicting ideologies or religious doctrines but a turf war. Indeed, the Orthodox Church, loaded with corruption, money-making, and full incorporation in the state bureaucracy, could hardly compete with Protestant and other preachers of the Western branches of Christianity who not only received no material benefit for coming to Russia but often spent their own money. This attracted believers and alarmed the Orthodox Church. Here, the Church was no different from the Russian state, which also is quite hostile to various Protestant denominations it cannot fully control. In driving the competitors out of Russia, the Russian Orthodox Church followed not its own interests, but also the commands of the state.

The Orthodox Church also followed the state in other ways. The present Russian state, and, consequently, the Russian elite, whom the state represents, have problems with the West. Still, they are basically Western-oriented, or at least regard the West as much closer to Russia than any other civilization. This is especially the case with West/ Central Europe. Sensing this inclination of the Russian authorities, the representatives of the Russian Orthodox Church have also demonstrated their basically pro-Western inclinations. For example, the Church believes Russia should be part of the European Union (Lenta.ru, 2008).

While for the Russian elite, Western European civilization is associated with the good life, in the minds of poor disenfranchised Russians who regard themselves as brazenly deceived by the rulers of the post-Soviet era, the West has quite a different meaning. It is often associated with their present misery, and they see the pro-Western orientation of the Russian Orthodox Church as helping the elite plunder average Russians. For quite a few disenchanted members of the populace, it is just a sign that the Church has abandoned both Christ and them-average Orthodox Russians. The Western orientation of the Church made its elite absolutely cynical and corrupt, quite similar to the Russian elite.

The passionate debate among the elite, or at least the middle class, as to what degree Russia should follow the West or retain its peculiar social/economic and political arrangements, is absolutely irrelevant for the poor. For them, regardless of any turn of state machinery or ideological twist, the state will be just as alienated from them. The struggle inside the elite and Russia's dealing-friendly or hostile-with the West are also not of much concern, and they watch these affairs with skeptical indifference.

While pro- and anti-Western elite and the Orthodox Church are pretty much the same in ignoring of the plight of the poor, the story is different with Diomid. In the view of his supporters he is poor, sincere, and not afraid to suffer for the cause. Diomid is a different fellow in their view-cut from different materials from the Russian elite both in and outside the church. This difference makes Diomid quite an appealing figure, and gives his philippics regarding church, state, and the entire social/economic arrangements of the post-Soviet era resonance among the populace. Even those 
who hardly share his beliefs see him as an extraordinary figure. Vladimir Solo'ev, the well-known Jewish commentator, stated that as a Jew he could not be seen as too predisposed to Diomid; still, he acknowledged that Diomid actually behaved as a saintly figure. Indeed, he could be seen as a living Orthodox saint (Credo.ru, 2008f).

Diomid also has supporters among the Church hierarchy. Nineteen priests, including Aleksandr Shargunov and Tikhon Shevkunov, signed a letter in support (Credo.ru, 2008g,h). His sincerity and true concern for the Church and people attracted not just conservative priests but even those with liberal leanings to his side. Igumen Grigorii (Lur'e) pointed out in an interview that Diomid is quite different from other members of the Russian Orthodox Church, especially its officials. These people are absolutely cynical; Diomid is very sincere; and, by exposing church corruption he has made the Russian Orthodox Church quite weak. He added that in the near future, the Russian Orthodox Church will lose the Ukrainian Orthodox Church. He stated in an interview that he had received a lot of letters in which people had expressed full support for his position (Anon, 2008).

Thus, Diomid represented the views of disenfranchised people who trust neither Westernized liberals nor official, so to speak, nationalists who believe that Russia as it is could uphold its position as an authoritarian Orthodox country modeled after the Byzantine Empire. For people of the Diomidian type, Russian Orthodox official nationalism and the Westernism of liberals and many of the Russian elite are hostile entities. All of them-nationalists inside and outside the church, Westernized liberals, and the conniving West-are scheming to bring harm to the Russian people, especially those with a true attachment to Orthodox Christianity. And they approached the movie from this perspective.

Some observers assume that the movie is a conniving plot of the West, that it is unable to boost Russians' morale and helps the Western elite mobilize public opinion against Russia. "Nikolai" noted that the movie is the result of a global political play (Nikolai, 2008). The USA spends a lot of money to study Byzantine history to promote American geopolitical ambitions. He implied that the movie itself could possibly have been instigated by the USA. The reason for this is simple. The movie demonstrates that Russians are still obsessed with the Byzantine Empire and global ambitions in general. This could be used by the US elite to scare its allies and the American masses and rally them against Russia. In this context, one should not be surprised that the West emerged as Orthodox Russia's enemy.

While the movie might well be designed as an ideological plot against Russia organized by the West, another interpretation is also possible. It could be seen as a conniving plot designed by the Russian nouveaux riches, who play the patriotic card while betraying Russian interests. "Soldier of Russian White Tsar-Emperor of Eurasia" ("Soldat Russkogo Belogo Tsaria-Imperatora Evrazii") stated that the movie was the creation of the Kremlin (Soldat Russkogo, 2008). It could be the beginning of Russian revanche, the real conflict with the West. But it could be just a satanic play by Putin, who under external patriotism continued to make Russia subservient to the
West. If so, Putin and his retinue will not escape punishment from the Lord. In this interpretation, true Orthodox Russians, betrayed by the Church and the Russian state, are doomed, and in the long run the Russian state is doomed with them.

These people have rather a gloomy outlook. For them, de-spiritualization and, implicitly, de-Christianization of the country-Christianity is obviously related to the purity of Orthodoxy-started when foreign influence brought Russia harm and started the country's demise centuries ago. Spiritual debasement goes along with the increasing power of the Russian state, which has become entirely alien to the majority of the populace. It also goes along with the increasing role of minorities, who have pushed ethnic Russians, especially true Orthodox believers, aside. There is some hope Russia can still stand on her feet, but the chance is not great.

Elaborating on this, a certain "Yuri K." proposed that Tikhon and the people behind him created the movie to mobilize the masses to defend the Russian state, but they actually showed that Russia, like the Byzantine Empire, is doomed. Throughout the centuries, Russia departed more and more from its healthy Orthodox archetype. The real Russia existed only before the thirteenth century (Yuri, 2008). During the Kievan period and shortly after, Russia was a free and purely Slavic Orthodox society. The implication is that Orthodoxy, received from Constantinople, was not tainted by political Byzantinism or in some other way. After this, Russians was exposed to the influence of other civilizations-all bringing the country and the people nothing but harm.

The Byzantine Empire, indeed, contributed to the shaping of the country's political culture after providing Russians with the gift of Orthodoxy. Still even at that time, the Byzantine influence was hardly benign. Indeed, the Byzantines did the same as the Mongols and, in a way, the West, after Peter. All of them brought Russia despotism and, in the case of the Byzantines, and implicitly the Mongols/ Tatars, ignorance. At present, "Yuri K." implied, after accumulating the negative aspects of all cultures, Russia is likely close to the end of its historical existence, and one should approach the movie and the more general ideological program of the regime from this perspective.

"Yuri K." stated that the authorities are quite logical in their ideological construction and brainwashing. The regime is in a big crisis, and for this reason the authorities try to prevent Russians from understanding the true depth of the problem by ideological make-believe. They spread ideas about Russia's essential health, all its problems notwithstanding. This illusion pertains not just to the regime but to the country and the people.

Russia is in deep crisis and could possibly be saved by some extraordinary measure such as fascist Germany used to save itself, "Yuri K." continued. Here, the Nazi revolution is seen as not so much a symbol of genocidal slaughter and imperial expansion as a conservative revolution that would return Russia to its pre-Mongol roots and conditions. It would be a country dominated by Slavs, grassroots democracy, and pristine Orthodoxy unpolluted by bureaucratic perversion.

Similar views are shared by others who see the ideal Orthodox Russia not so much as pre-Mongol but as pre- 
Petrine; their views, of course, are quite similar to the Russian nineteenth-century Slavophiles who saw in Peter the Great the polluter of true Russian culture.

Andrei Ezerov stated that the Byzantines are "our everything. I love more only Moscow Russia” (Ezerov, 2008). The Byzantines and Moscow-Russia are a model for "conservative revolutions," and he wished these revolutions to take place in Russia. They would spiritualize the country and bring it back to its true Orthodox roots. Still, he did not believe that this would happen.

Mariia (2008) had an even gloomier outlook and saw no hope for the country's spiritual revival. For her, the Russian elite and even the Church have degenerated. They were Orthodox by external trappings but actually anti-Orthodox, even anti-Christian in their essence. She noted that, while some skeptics assume Russians are spiritually degenerate, the majority of those who believe in the importance of Orthodoxy still hold the notion that Russia is basically an Orthodox country. The West could not stand Orthodoxy with its high spirituality. This explains Russia's perennial conflict with the West. Russia and the Byzantine Empire were, indeed, great states when they followed strictly the maxims of the Orthodox Church.

While true believers in both Russia and the Byzantine Empire continued to uphold the maxims of Orthodoxy, the elite and even the Church actually became godless. This can be seen in Russia today. The Russian elite and the Church's approach to the Jews is a good illustration of this degeneration. The Jews prepare kosher food in the Kremlin, the Russian Orthodox holy place, and celebrate Hannukah on Red Square-another sacred place. This is supported not only by the Russian elite but even by the Orthodox Church. Moreover, Medvedev is actually a Jew.

Thus, for those who support Diomid and whose views could be compared with those of 17th century "Old Believers" or idiosyncratic Protestants, the present hierarchy is betraying Orthodoxy; and Diomid's supporters are calling for the return of Orthodoxy to its pristine past.

\subsection{Pagan response}

For others, Orthodoxy itself is one of the sources of evil, and Russia's liberation would return Russia to its preOrthodox Christian past. The deep alienation of quite a few ethnic Russians from the present state, and Orthodoxy as an integral part of it, as well as the rise of Russian nationalism, have led to a curious resurrection of paganism in its "most primitive (grubykh) manifestations" (Islam News, 2009). Neo-paganism apparently started in the 1990s, directly inspired by the European and American Right. Their approach to Christianity was not consistent. Some of them tried a rather curious way to combine racism, a sort of implicit paganism, with Christianity. And here some of them were definitely influenced by American racists. One of the essential problems with American racism was that the white population in the USA-the historical melting pot-had a much less developed sense of belonging to particular ethnic groups defined in purely biological forms, quite different from the majority of SocialDarwinist racists in Europe in the second half of the nineteenth-century. The strong role of Christianity, especially in the Protestant versions, as the essential attribute of the white members of society also made it impossible for them to shake Christianity as a harmful attribute as easily as had been done by the Nazis in Germany. This notion of "Aryanism," which persisted among American Neo-Nazis, was combined with a curious blend of paganism and respect for Christianity. The same curious mix of neopaganism with Christianity could be seen in the Russian Orthodox National-Socialist Movement (RPNSD). The supporters of the movement promulgate their support of "religious-racial doctrine." According to the proponents of this doctrine, Aryan people-Russians are seen Aryan-are the real Christians and Jews, the chosen people. The people who call themselves Jews have nothing to do with Judaism and the majority of the people who call themselves Christians have no relationship with Christianity. The curious combination of racist neo-paganism with Christianity could also be seen by the fact that Hitler was dubbed "Christloving Leader" (Shekhovtsov, 2007).

Some representatives of Russian racist neo-paganism are not consistent in their denial of Christianity, others are more so. This latter group, influenced by the European Right, regard Western civilization as primarily the civilization of the white man-Jews are not seen as part of the white community. They see Christianity as evil, one of the ideological backdrops of "political correctness," which helps nonwhites engage in extermination or at least marginalization of the white man in the heart of the white worldEurope and the USA. Following the "European Sinergia" pattern, groups of racist neo-pagans emerged in Russia by the 1990s. One group, led by Vladimir Avdeev and Anatolii Ivanov (Skuratov), had as a vehicle the journal Nasledie predkov (The Heritage of Ancestors). Avdeev apparently was the major ideologist. This neo-paganism became complete in the sense that Avdeev not only emphasized the centrality of race in human history but also regarded Christianity as absolutely foreign to Aryans, Russians, of course, included (Shnirel'man, 2007: 190).

Racist neo-paganism continued to spread. In the 2000s, books with these ideas were actively integrated in the educational process in some Moscow colleges (Shnirel'man, 2007: 205). An international conference, at which the notorious David Duke, former Grand Wizard of the Knights of the Ku Klux Klan in America, was present, was held June $8-10,2006$, in the building of the International Foundation for Slavic Culture and Language (Mezhdunarodnyi Fond Slavianskoi Pismenosti i Kultury). By 2009, there were at least 20 groups of neo-pagans/pagans (Rosbalt, 2009a). Apparently, they often engaged in various criminal activities, from vandalism to murder (Kozhevnikova, 2007: 38). These groups, expressed strong dislike of Christianity and other monotheistic religions in the Russian state, even in its present form. They believed that Christianity was hostile to ethnic Russians. They professed support of "Slavic separatism" (Ukolov, 2009), e.g., shedding ethnic enclaves of the Russian Federation where Russians could not dominate completely. Some neo-pagans engaged in terrorist activities. One group, for example, was led by a seventeen-year-old girl, who had instilled other members of the group with the ideas of paganism (Grani.ru, 2009), or at least was converted to paganism, together with the other members of the group. 
Besides considering those who do not look Slavic or non-European, the neo-pagans also look at priests as their enemies. Logically, Orthodox churches and priests are among their targets (Anon, 2009; Rosbalt, 2009b,c; Zaritovskii, 2008; Zheglov et al., 2009). In this new edition of paganism, pre-Christian Russia is considered the ideal society. The Byzantine Empire is seen as an Orthodox state that brought Christianity; Christianity is viewed as irrelevant, or even hostile, to Russia.

Here, basically two models exist. According to one model, the harm brought by the Byzantines and Orthodoxy was, in many ways, due to the fact that both actually represented Asians, whose ethnicity/race and culture were deeply hostile to white, purely Aryan Russians. Russians were truly democratic, freedom-loving, highly advanced people. The suppressive Byzantine Empire and Christians in general were people with an implicitly Asiatic slant. Consequently, Christianity could bring Russia nothing but harm either in the past or in the future.

The other model implies that the Byzantines and Orthodoxy were harmful for Russia regardless whether they were Asiatic forces or not. Neo-pagans-one could assume that neo-paganism is an essential ingredient in the ideology of a considerable number of rising Russian rightwing and often neo-Nazi extremists-are strongly antiAsian. One need not engage in a detailed study of their outlook. Their actions provide enough information about their views. Asians, what Russian extremists usually call people of "Caucasian nationality"-anyone who comes from the Caucasus and who looks swarthy-are the major target of their attacks. Thus, this basically anti-Asian attitude had been telescoped from the past and reflected in the neo-pagan views of the Byzantine origin of Christianity and the Mongols and their role in Russian history. These views on all these periods of history are interconnected.

Neo-pagan views on the Mongols are distinctly different from what one sees in Neo-Eurasianists, the proponents of the creed popular in the late Yeltsin/early Putin era. For Neo-Eurasianists such as Alexander Dugin, the Mongol invasion was a fusion of Asians and Orthodox Russians that led to a "symbiosis" of two similar peoples. Racial and cultural/religious differences were downplayed, and Mongols and Russians were seen as having "complementary" cultures. For this reason, the Mongol Empire was praised as the builder of Russian statehood. This vision of the Mongols was resolutely rejected by neo-pagans. They regard Mongols as culturally and especially racially foreign to Russians. This negative vision of Asians in general could be seen in Internet discussions centered on the discussed movie, in which some who seem to be neo-pagans were engaged.

Elaborating on the rule of Mongols in Russian history, one commentator (Chernyi-Foma-Aleks, 2008) noted that while uncivilized themselves, they were in touch with the great civilizations of the Orient, such as China and Iran, and transmitted this great cultural historical tradition to Russia. For other observers, the Mongols were absolutely negative. One stated that the Russians could hardly have gotten anything from the Tatars/Mongols. Russians see Mongols only in the capacity of looters. The Mongol invasions played quite a negative role in Russian history.
The profound anti-Asianism that permeates neopaganism led to a peculiar vision of Byzantines and Orthodoxy, in fact, of Christianity in general. In this approach, Asia was not opposed to Byzantinism and Orthodoxy, as was the point of Russian social thought and historiography for centuries. Byzantinism, Orthodoxy, and even Christianity in general became deeply integrated with Asianism. Consequently, Asianism penetrated Russian statehood and political culture from all sides. The ugly aspects of Russian political culture come not just from the Mongol Empire but also from the Byzantine Empire and even Orthodoxy, Christianity in general. This all-embracing Asianism led to tragic results for the Russian people: a state prompted by Asiatic Orthodoxy, which subjugated the Russians-European people. Their suffering from these Asiatic foreign entities a long time ago continues to the present.

\subsection{Russians as the victims of despotic Christian Asiatics}

The viewpoint of "Navod," one of the commentators on the movie, illustrates the views of those who believe that since time immemorial Russians, wholesome Aryan pagans, were subjugated by alien Asiatic forces.

In an Internet discussion, "Navod" proclaimed himself a Russian patriot and a member of the nationalistic organization Pamiat' (Memory) since 1985 (Navod, 2008). He cannot understand why Byzantinism and Orthodoxy are so important, for pagan Russia was a highly civilized and developed country of free people whereas the Byzantine Empire was a slave-owner society. In addition, Russia was much older than Byzantium. Russia has at least a ten- to twelve-thousand-year-history, and it is absolute sacrilege to glorify the Byzantine Empire and see it as the spiritual forefather of Russia. Slave-owner despots and free pagan Russians were too different not to be sworn enemies. Naturally, "Navod" pointed out, an enclave of thousands of Russians could not stand this abomination. The Russian princes Oleg and Sviatoslav attacked the Byzantine Empire not because of vanity but because they regarded it as their duty to liberate their brothers and sisters from slavery. The Byzantines were not able to defeat and subjugate the freedom-loving and bellicose Russians. But they found a way to accomplish their goal by other means: they seduced the Russians with Christianity.

"Navod" continued that the Russian Baptism was nothing but a form of subjugation of peaceful Russians by the Byzantines. The emperor used enormous resources to ideologically and physically subjugate Russia, with Vladimir, supported by an army of foreign mercenaries, as a stooge. In 988, the Byzantines installed in Russia a Quisling type of regime. Vladimir, the puppet, engaged in genocide against the Russians and provided considerable booty to the Byzantines. Those who followed him did pretty much the same. It is not surprising that the period from 988 to approximately 1500 (the Byzantine collapse) was one of the darkest eras of Russian history: Russia was actually a colony of a sort of the Byzantine Empire.

One should remember that Mongols/Tatars ruled Russia from the 13 th to the 15 th century. This replacement of what most Russian historians called the Mongol/Tatar Yoke by 
a sort of Byzantine Yoke implied that Byzantines and Mongol/Tatars were pretty much the same, and that Byzantine rule over Russia was the rule of Asiatics over European, Slavic people. Although Russians finally liberated themselves from the Byzantine yoke, it was reinstated in a way in present-day Russia.

Similarities between Russia today and the Byzantine Empire can be easily seen, according to "Navod". The empire was a predatory state that lived on fraud and pitiless exploitation of periphery peoples, approximately as Moscow does with the rest of Russia now. The current regime clearly continues to treat Russians in the old, oppressive Byzantine/Orthodox fashion and clearly demonstrates the pro-Asiatic, actually anti-Russian inclination of the Russian state. Indeed, Moscow rulers clearly helped the Muslims. The misdeeds of the Byzantine Empire are perpetuated now by people from the Caucasus. They kidnap Russian girls and enslave them as sex toys or sell them for the harems and brothels of the Middle East. While brutal Asiatics continue their mistreatment of Russians, the Russian state does nothing. It is obviously on the side of Asiatics and so perpetuates centuries-old traditions.

The connection of the Byzantines with Muslims and the implicit attempt to "Asiatize" people could be seen in other comments. For example, Vales (2008) noted that the Byzantine Empire was an "Asian Middle Ages empire" and its death of hardly any concern to Russians. Russians should be glad of the collapse of the oppressive Asiatic empire and the weakening of Orthodoxy, which is also implicitly connected with Asia and a force hostile to Russians. Elaborating on the essential hostility of the Orthodox Church and Russian state to ethnic Russians, Porudchik (2008) noted that, according to historians, by the tenth century one-third of the Slavic population in Russia had disappeared, replaced by non-Slavs. This displacement or actual elimination of the Slavic population was the handiwork of the Orthodox Church and the Russian elite, an Asiatized force. This Asiatization of the country, the elimination of healthy European/Asian Aryan Russians and replacement by worthless Asiatics, had profound implications for the country's future. This presence of Asiatics in Russia has weakened the country. This made its conquest by other Asiatics-Mongols-200 years later an easy enterprise. Indeed, "Porudchik" implied, some Asiatics in Russia welcomed the Mongols, their racial kin. The Slavic/Aryan population was too weak to fight the Mongols, and as a result became enslaved by them.

Some people, however, praised the Mongols as the builders of a great empire. They claimed that Russians were happy and proud to be part of the Mongol Empire because Russians and Mongols lived in a condition of happy "symbiosis." The Mongol Empire was a Russian empire as well, or at least it helped Russians create a great empire in the future. "Porudchik" pointed to Alexander Dugin, the well-known supporter of Eurasianism/Neo-Eurasianism in Russia, who sees unity/symbiosis between ethnic Russians and the non-Slavic, mostly Asian, people of Russia as the source of the country's strength.

Dugin and similar-minded Eurasianists also downplay race as an essential aspect of nations, however, and "Porudchik" could not accept this. He mocked Dugin, who wanted Russians to be united with the Mongol-Tatars, as well as those who looked at the Byzantine Empire as Russia's origin and the model to follow. These people not only held that Russians should be united with racially alien Asiatics but also downplayed the racial aspects of the Russian people as a source of their strength. This source is their bloodline. The real ancestors of the Russian people are Scythians, a truly Aryan people; this people's history and achievement was the real source of Russian strength, not the openly Asiatic Mongol Empire or cryptic Asiatic Byzantines and Orthodox. Elaborating on Russians' achievements as a pagan people (paganism as truly a religion was juxtaposed to Asiatic/crypto-Asiatic Orthodoxy, Christianity in general), "Porudchik" noted that Russians indeed created a great empire. They did so not with the help of but despite Orthodoxy and the Russian state. These were on the side of the Mongols, sworn enemies of the Russian people and Russian empire. The anti-Russian policy of the Russian Orthodox Church could be seen by the fact that Metropolitan Cyprian anathematized Dmitry Donskoy when he was ready to fight the Mongols.

For some observers, the Byzantine Empire and Orthodoxy were both Asiatic institutions and ideologies; and hence harmful for Russians. Other observers had modified views. They did not claim that the Byzantines were Asiatics or that Orthodoxy was an Asiatic creed. But they believed Orthodoxy had been harmful for both Byzantines and Russians. "Silovik" (2008) (a member of the security agency and military) stated that Orthodox Christianity brought no good to the Russians or Byzantines. One should not overestimate the role of Orthodoxy in the fate of nations. The Russian state emerged when the elite were pagan. Sviatoslav, actually Svendisleif (here "Silovik" implied he was a Viking), was pagan, and this did not prevent him from defeating the Jewish Khazar state. Orthodoxy also hardly inspired the Byzantines to defend their country. Constantinople had many people, but only a few thousand defended it against the Turks. Not only did Orthodoxy transform people into unpatriotic cowards, it also blinded the rulers and made them unable to make the proper geopolitical moves.

In "Silovik"'s opinion the problem with the Byzantine emperors was not that they were betrayed and corrupted by the West but that they cavorted with Asians. When the crusaders entered the Holy Land, the Byzantine emperor, instead of helping, actually ordered Pechenegs to attack them. Thus, Byzantinism/Orthodoxy brought nothing positive to Russia. Even those who do not see in them an Asiatic force hostile to Russia, representatives of an alien culture, still consider the Byzantine tradition a deadly potion of abusive practices that has harmed Russia up to the present. Indeed, the Byzantine Empire is still alive in Russia today, a tradition of abuse and corruption.

Another contributor, "Rus" (2008), noted that bringing Christianity to Russia led immediately to the end of ancient Russian liberties. Christianity suppressed Russian traditional beliefs and led to the rise of brutal and repressive powers. This tradition of abuse survived to the present and is the real legacy of Byzantium. "Rus" noted that he saw Byzantinism every day in Russia, in the criminality and abuse of power by the authorities. This policy, perpetuated by Putin and 
Luzhkov, is the very embodiment of Byzantinism. It is the source of all present problems, "Rus" believes.

The reference to Luzhkov, mayor of Moscow, underscores the deep hostility to Moscow among provincial folk who regard it as a parasite who lives at the expense of others. It also indicates lingering separatist feelings, the desire to make the centralized state as weak as possible. This could be seen even more clearly in other comments. "Patriot Sibiri" (Patriot of Siberia) (2008) noted that the Byzantine Empire started to flourish anew when the capital was transferred from Constantinople to another city. The same should be done in Russia. Instead of Moscow, the capital should be placed in a city in the Urals. Makar (2008) fully supported this idea and said the capital should be in Novosibirsk. "Siber v NATO" (2008) noted that the capital is not needed at all, and each Russian region should have broad self-government.

\subsection{Ethnic minorities as a problem}

For some, the major reason for the collapse of the empire was the loss of ethnic homogeneity. The problem with the Byzantine Empire was not that it had lost its Orthodox purity. The empire was not a monoethnic state and included a lot of minorities. It was actually an "Armenian-Greek" state, and its people thought about nothing but money. Such a state could not be stable, and it was not surprising that it fell under the pressure of "peoplewarriors" (Sergei, 2008).

Other observers shared similar ideas. The major reason for the collapse of the empire was that it had lost its ethnic cohesiveness and become polluted by minorities (Il'ia, 2007). Therefore, disenfranchised members of Russian society who watched Tikhon's movie regarding the history of the Byzantine Empire believe it sent a potent signal for the fate of the Russian state. Russia, in their view, could disappear or exist only as a state deeply foreign to the interests of the majority of Russians.

For some, supporters of Diomid, salvation would be in return to true Christian roots; for others, neo-Nazis and neo-pagans, it was return to the pre-Christian past. All of them implied that return to what they regarded as true Russia was a difficult enterprise, but some did not regard this enterprise as entirely impossible. If this happened, Russia would reemerge as the country of Russian people and be a prosperous state. Still, for some Russian intellectuals who appeal to the history of the Byzantine Empire, in connection with Tikhon's movie or on other occasions, Russia has no hope. Like the Byzantine Empire, Russia will perish because all empires perish sooner or later.

\subsection{The death of empires as a natural process}

For some Russian intellectuals, the death of the Byzantine Empire, the collapse of the USSR, and Russia's future collapse are simply a natural process. Everything that is born dies sooner or later. The inevitable death of the state/ empire does not necessarily have negative implications for Russia. This was the case with the supporters of the idea, "Russia for Russians," with their strong isolationist philosophies; for them, any empire, actually any big state, is harmful for Russians, for in all these the minority and minority-supported bureaucracy live well at the expense of ethnic Russians. In this context an empire is not Russia's salvation but its curse.

One could compare the Byzantine collapse with that of the USSR and not be upset with Russia's losing its imperial greatness. Indeed, some participants in the discussion argued, Russia should not be dismayed about the collapse of the empire: if the USSR were still present, Russians would have been obliged to share oil income with other republics. This theory implies that Russia in its current form is not big and has too many minorities who live at the expense of ethnic Russians, reducing Russia's size even farther. Shedding the ethnic enclaves would homogenize Russia from an ethnic point of view and ensure its survival and even prosperity as a true Slavic/European state.

This praise of the end of the empire is not dominant, at least among those who ponder Russia's fate in the Byzantine scenario. For most of these, the collapse of the USSR will lead to the disintegration of the Russian Federation without positive implications for Russians. Russia will not emerge after these changes (shedding its imperial and mostly non-Slavic heritage) as an ethnically homogeneous and prosperous Slavic state-possibly part of Europe-but will disappear for good. And the end of Russia will be the end of the Russian people.

An important aspect of these views-of course, in the context of Byzantine history - is that Russia's and Russians' death is not something special but a natural process. One might guess that Lev Gumilev influenced the writer. Gumilev, a Eurasianist, believed in a natural symbiosis between Russian and Turkic people. At the same time, his theory had another aspect. Gumilev blended Social Darwinism of a sort with the philosophy of Russian cosmism; the influence of Alexander Chizhevsky could be regarded as most important. For Chizhevsky, the cosmos had a direct influence on social processes of the earth, including revolutions. In Gumilev's interpretation, Chizhevsky's approach was "Darwinized." The cosmic process, the impulses one receives from the cosmos, led to the emergence of ethnos and what Gumilev called "superethnos," a quasi-biological organism that moved through the stages of birth, youth, maturity, and death. Gumilev's approach is clearly also similar to that of Oswald Spengler, albeit it is not clear that Gumilev was aware of Spengler's existence when he created his theory. The "Gumilevian" idea about the natural death of nations was often employed by those who believed Russia had achieved the limits of its historical existence and would die in the foreseeable future.

In this respect, Russia is similar to other states/empires of the past. Like the Byzantine and Roman empires, Russia will fall apart and disappear. The process that started with the disintegration of the USSR was just the beginning of the complete collapse of Russia as a state and civilization. This assumption is shared by the protagonist of the novel After Russia (Posli Rossii) (Krasheninnikov, 2008). Fedor Krasheninnikov, the author, from Ekaterinberg (Urals), visualizes the final disappearance of Russia in the not too distant future; Roman and Byzantine history help the protagonists understand the reason and meaning of the event. The novel, published on the Internet, described the situation in 
Russia at the beginning of the 21st century. Russia had ceased to exist after a crisis that followed what seems to have been unshakable prosperity. (Interestingly enough, this statement about the imminent coming of a great crisis was made before the 2008 economic crisis, which has affected Russia, together with other parts of the world.) During this crisis, the weakness of the present Russian Federation was revealed immediately. One of the protagonists remembered a meeting of representatives from the different regions of the Russian Federation. They all spoke Russian, but they had absolutely different interests and looked like people from completely different countries with no ties to keep them together besides the direct power of the state. And, as soon as the state became weak as the result of the crisis, Russia immediately fell apart.

Russia's friends and neighbors, ranging from great powers such as the USA and China to republics of the former USSR, immediately took advantage of the situation and tried to make the disintegration of the country permanent. They each had their sphere of influence in postRussian space. They also encouraged the development of local separatist ideologies. The local elite also tried to instill the local populace with the belief that there were no such people as Russians: there were separate people, such as Siberians or Uralians, who had nothing in common with each other. Moreover, these ideologists tried to convince the locals that the Russian state in the past-with Moscow as its epitome-was their natural enemy. Still, some people of these states remembered Russia and wished to bring it back to life. This led to uprisings led by Pirogov, who was able to reassemble most of the Russian Federation around Moscow. Pirogov's enterprise did not last very long, and his new and last Russia finally collapsed.

The reasons for Pirogov's debacle were manifold. To start with, the possibility of Russia's resurrection alarmed the other powers who were used to dominating postRussian space and eager to exploit anti-Moscow feeling among its residents. Another-the author implied-even more important reason why Pirogov's enterprise failed was the attitude of the majority of the residents of this postRussian space. Their attitude was compared to that of those who lived in the territories of the Roman and Byzantine empires during their decline. Similar to the Romans and Byzantines, as well as the barbarians who took the land of the two empires, the residents of post-Russian space had no attachment to the state, in Russian or especially Soviet form. They saw it as an alien body. Consequently, they had no nostalgia for a grand imperial past and did not care what happened to post-Russian space in the future.

Seva, another protagonist, stated that the present residents of the various Russian republics had no nostalgia for the USSR. They could be compared with the barbarians after the collapse of the Roman Empire: they had no emotional attachment to their Roman heritage and could use pieces of Roman temples to build toilets (Krasheninnikov, 2008: 59-60). Thus, like the Roman and Byzantine empires, Russia is doomed. Other protagonists pointed out that, like the residents of those empires, Russians could hardly do anything to prevent the final collapse (22-23). While not able to prevent its demise, they could at least choose the way their state would finally disappear. As Pirogov himself started to ponder about the ultimate and apparently irreversible process of disintegration, images from the Byzantine and Roman past started to emerge in his mind.

At the beginning of Pirogov's venture, he seems to have been quite successful. While most Russians were passive and uninterested in anything not directly related to their personal interests, some retained the memory of Russia's past glory and supported Pirogov. But this drive for Russia's unification was dashed. Most of Pirogov's initial supporters soon lost interest in the enterprise. His right-hand man became a degenerate neo-Nazi with no understanding of reality. The apparatus of power Pirogov tried to recreate from the bureaucratic material he inherited from the previous regime was absolutely rotten. Even the Orthodox Church was of no help in his endeavors. Some provincial church leaders joined the separatists on this or that excuse; even the Patriarch was an opportunistic and self-seeking individual who thought mostly about his personal career and security rather than the interests of Russia and even the Orthodox Church. Watching the behavior of the Church and bureaucracy, Pirogov thought he should purge all of them and believed that shooting all this scum would be a last gift to the Russian people. While outraged by the behavior and attitude of the elite, Pirogov himself was not up to his role as Russia's deliverer. He was a vain person who was soon infatuated with the external trappings of power and engaged in numerous love affairs.

While the Moscovite elite and those who initially supported Pirogov's project were not up to their grand task, foreign powers easily exploited the lingering anti-Moscow feeling among a considerable number of provincial folk and led an anti-Pirogov army against Moscow. Watching his enemies approach, Pirogov immersed himself in gloomy meditation and engaged in comparing the approaching demise of the Russian state with the ends of the empires of the past. Roman/Byzantine history became the most appropriate example.

Pirogov noted that the Roman Empire had collapsed in two ways: the collapse of the Western Empire and the bloody end of the Eastern Empire. He wondered what kind of end Russia, unified after disintegration, would choose (Krasheninnikov, 2008: 22, 23, 101, 102). Actually, the end of the Russian state was something in between. After one Pirogov victory, the anti-Pirogov forces entered Moscow, and Russia finally and irreversibly fell apart. The author implied that Russia's end was, in many ways, predestined, for the country had reached the limits of its historical existence. Pirogov's attempt to resurrect it was ill-fated, like attempt of some Roman and Byzantine emperors to prevent the complete demise of their empires when they had reached their natural historical limits.

Other Russian authors with similar views and interest in Byzantine history also had a chance to present their pictures of the past on the Internet. Sergei Cherniakhovsky, author of the historical essay "Byzantinism as Agony" (Cherniakhovskii, 2008) pointed out that the rise and the collapse of the empire is a natural process-here, he implicitly evokes Gumilev. The Byzantine rise and fall was basically unrelated to the specifics of Byzantine civilization, 
he argued. It had nothing to do with Orthodoxy or other peculiar characteristics, but followed the models of other empires and collapsed under the pressure of young and vigorous people when it reached its lifespan.

A certain Galler (2007) also evoked the theory of the still popular Gumilev in analyzing the Tikhon movie. He said that those who created the movie should read Gumilev, and this would explain to them the reason for the end of the Byzantine Empire. The appeal to Gumilev was also made by another observer, who stated that Russians should not study anyone, including the Byzantine Empire, or try to find in Byzantine history all sorts of crystal balls for predicting the country's future. What is now going on with Russia should not perplex anyone. Russia is just following its national historical process. It is now in a phase of "inertia," and, according to Gumilev, it will last another 300-400 years (Leonid, 2008).

The evocation of Gumilev has different implications. It shows not just that death is an unavoidable, natural process but that even countries blessed by history-Gumilev sees the Mongol/Tatar/Russian "symbiosis" as a unique combination that ensures the stability of Eurasian civilization-finally die. This sort of idea could be found in the comments of "Petia." Petia (2008) asserted that Russia had several historical blessings of a sort. To start with, it was an Orthodox country. Orthodoxy, indeed, made Russia a strong power that was able to stop the Mongol onslaught on Europe. Russia was not actually conquered by the Mongols but engaged with them in a sort of healthy Eurasian symbiosis. As a matter of fact, Russia was able to combine the advantages of Orthodoxy with those of the Mongol tradition. But even these advantages could not save Russia from a younger and more vigorous civilization, such as Islam. The onslaught of Muslims against Orthodox civilizations, Christians in general, started long ago with the collapse of the Byzantine Empire, which fallen under the pressure of the Muslims. The same fate is in store for Russia: after the defeat of the Westerners, Muslim extremists will strike Russia.

The assumption that the death of the empire is a natural phenomenon is shared even by those who assume some action could delay the demise. Aleksei Murav'ev (2008) stated that Tikhon's movie had a very clear political message. Russia could follow several essential rules to avoid the fate of the Byzantine Empire in the foreseeable future. A strong dictatorial government is important. So is avoiding ethnocentrism or transforming ethnic groups of the empire into foreign entities, which would doom the state. Efficient policies could also have prolonged the life of the Byzantine Empire and could do so for the Russian state. But these policies cannot avert what is inevitable. In Murav'ev's view, the death of the empire is caused by natural reasons. Every empire will die sooner or later.

While for Murav'ev the empire will not live longer because it has not taken Tikhon's medicine, e.g., instilling all ethnic groups with the feeling of trans-ethnic belonging to the same state, for others the situation was essentially different, and the empire's demise has hastened the rejection of the West. Since the Russian rulers will likely follow Tikhon and reject the West as a true partner, Russia will most certainly follow the Byzantine fate.
A certain "Maliuta" implied that the Byzantine Empire lived much longer than it should have. Orthodox Byzantines had no desire to defend the emperor. So for several hundred years it existed only because it was defended by Western Catholic mercenaries. Because of the help of the West, the Byzantine Empire was in the process of dying for 500 years.

Maliuta (2008) implied that present-day Russia is quite similar to the Byzantine Empire. Like the Byzantines, Russia is under the pressure of the Muslims and survives only because it is protected by the West. The elite understand that Russia's collapse would lead to the general collapse of Christian civilization. But the West will not be able to prevent Russia's inevitable demise; and from this position Russia will follow the road of the Byzantine Empire. The only difference is that the process will be much quicker and Russia will die in a much shorter period of time. Russia will follow the road of all states and die sooner or later.

Even the participants who did not subscribe to the theory that all empire/states are doomed still believed that comparison of the present-day Russia with the Byzantine Empire hardly augurs well for the Russian state and even the Russian people. Ivan (2007) noted that not only did the Byzantine Empire but the Byzantines as a people disappeared. Thus, he is hardly pleased by the comparison, and hopes that Russia and the Russians will avoid that ignominious end. Still, he is afraid his hope may be in vain.

Other observers seemed to entertain the same thought. Liuger (2008) implied that Tikhon assumed that Russia is a new Byzantine Empire. If so, he would like to know whether Russia is now in the year 1204 or 1453 . Neither comparison is very pleasing for Russia. Constantinople was taken by Western crusaders in 1204 but was resurrected for a while. In 1453, Constantinople fell to the Ottoman Turks. After this, there was no resurrection. "Liuger" believed Russian may be closer to 1453 than to 1204 .

Finally, there were observers who believed Russia is the worst of all possible worlds. They imply that the death of states/empires is not predestined. Still the point is that Russia is not a viable state. Innokentii (2008) elaborated on this in his comments. He argued that both the Byzantine and Mongol ingredients in Russian culture make its situation hopeless. That is, even the most benign cultural achievements of the West reinforce despotic ugliness and cultural-political and geostrategical retardation, so to speak. He considers Russia's achievements illusory, actually nonexistent. Russia may survive for a long time because of extraordinary luck or a combination of the circumstances. But this luck cannot continue indefinitely, and Russia may well be approaching the end of its historical existence. The authorities quite possibly understand the depth of the crisis. If, nevertheless, they attempt to imitate the Byzantine Empire, this will just hasten the final and irreversible end. From this perspective, Innokentii Pavlov fully supported Valeriia Novodvorskaia and pointed to Vladimir Solov'ev's famous poem prophesying that Russia's attempt to follow the path of brutal Byzantium would lead it to disaster. Similar to Byzantium, Russia will fall under the onslaught of the Asiatics. 


\subsection{Conclusion}

Tikhon Shekunov's movie on the collapse of the Byzantine Empire, created at the very end of Putin's presidency, led to broad public response. The comments provide opportunities for a snapshot of the ideologies and trends prevailing in Russian society. For conservative Russian nationalists the Byzantine experience indicated that Russia should preserve Orthodoxy and the authoritarian tradition as the foundation of its political/ideological edifice and avoid the pernicious influence of the West. The West is a mortal threat for Russia as an Orthodox civilization. Westernized liberals have opposite views. They believe that the Byzantine Empire did not follow the road of the West, and regarded it as its mortal enemy. This was a crucial mistake, for this policy exposed the Byzantine Empire to the onslaught of Asiatics. The same will be the fate of Russia if it shuns the West and see it as Russia's enemy.

Both conservative nationalists and liberal Westernizers are part of the Russian elite. The movie made it possible to gauge the responses of a considerable number of disenfranchised Russians. What can be seen from their views? The first point that became clear was the profound pessimism of all groups. The supporters of Diomid, the renegade priest who, in a way, rolled together in his personality both Russian Old Believers and European Protestants, believe that Russia is, indeed, similar to the Byzantine Empire during its decline. Both countries abandoned Orthodoxy and tradition in general and were doomed to destruction regardless of anything they did. The numerous neo-pagans believe that since the 9th century or possibly earlier Russia has been controlled and exploited by an unholy alliance of the Orthodox Church, Jews, and Muslims.

Finally, a great many Russian intellectuals with no clear political affiliation but deeply alienated from the present situation see Russia as doomed like the Byzantine and Roman empires plainly because everything that is born shall die. The depth of this pessimism is truly remarkable if we recall that the movie and discussion were launched at the final stage of Putin's presidency, when there was an endless stream of hard currency, oil/gas prices were rising, and Russia enjoyed an economic standing as never before.

The other essential characteristic of all these observers is a strong anti-Muslim and anti-Asian bias. The fantasy of Eurasianists (e.g., Gumilev and Dugin) about the healthy symbiosis of Orthodox Russians and Muslims of various ethnic backgrounds is absolutely foreign to this discourse. In fact, Gumilev, extremely popular in the late Gorbachev and Yeltsin eras, was rarely mentioned, and not to emphasize a healthy symbiosis but to recall the quasibiological evolution of ethnos/"super ethnos" through youth, maturity, aging, and death. And while Gumilev believed Russia is still a young state/nation and thus can expect a long life, the observers had quite different views. For them, Russia is an old and dying state. The disintegration of the Russian empire starting with the collapse of the USSR is not finished, and further disintegration of the Russian Federation is to be expected, leading to a final demise of both country and people. This isolationist, separatist, and disintegrationist feeling are shared even by those who, regardless of profound pessimism, still believe Russians may live better in the future. This group-mostly neo-pagans-see the way to a better future in the actual disintegration of the present Federation. The anti-imperial, anti-expansionist feeling is pervasive.

While all those who engaged in the discussions discard a stable alliance with Asians, some of them, e.g., neopagans-had positive views of Europeans. For them, Russians and Europeans are kindred Aryan people who are subjugated by an unholy alliance of Jews, Muslims, the Orthodox Church (Russia), and "politically correct" minorities/stooges (the West). Both should shake off the foreign yoke and live peacefully together.

What is the implication of these views for Russia's politics, especially now when Russia, together with other parts of the world, has entered a period of long and quite possibly serious economic troubles? It is clear that Russia's imperial drive to resurrect the USSR in this or that form is quite limited, and the Georgian War is an aberration rather than a resumption of the drive. Recent project to create "Eurasian Union" should be also approached with grain of salt. Most Russians, especially those from disenfranchised groups, are either self-centered Russian nationalists or Western-oriented. One could also argue that, with all this dislike of the regime, these people would hardly stand against it in open confrontation. From this perspective they could be similar to the majority of Russians who, despite the occasional and still limited, mostly antiminority riots, e.g., in Kondopoga and Stavropol-remain basically passive.

However, this passivity is related to the sense that not only is the present regime absolutely foreign-according to some observers, Russians have never had a government that addressed their interests-but, even in the future, the changes, regardless of all combinations of events, would not be for the better. This suggests that these people, while not ready for open revolt, would not render visible support to the state in case of a crisis. This also implies that in such a major crisis the Russian Federation could well follow the road of the former USSR or transform itself into a new edition of the Holy Roman Empire. It could also combine both scenarios in an idiosyncratic and absolutely unpredictable form.

\section{References}

Anon. (2007). Kak raskruchivaetsia el'tsinskii stsenarii. http://stopdiomid. iboard.ws/viewtopic.php?id=1 8 January.

Anon. (2008). Ia ostaius' vernym RRTs MP. http://www.rons-inform.org/ more.html?id=812_0_20_0_C 7 August.

Anon. (2009). V Moskve likvidirovan boevoi otriad terroristov-iazychnikovReportazh. http://www.5-tv.ru/news/16435 21 January.

Cherniakhovskii, S. (2008). Vizantizm kak agoniia. APN, 19 March.

Chernyi-Foma-Aleks. (2008). Comments. http://www.apn.ru//publications/ comments19489.html 19 March.

Credo.ru. (2008a). Episkop Diomid gotov sest' v tiur' mu i nazyvaet svoego glavnogo gonitelia 'bankirom vodochno-tabachnym mitropolitom'. 11 August.

Credu.ru. (2008b). Ivan Pavlov.Diomid-detishche 'Proekta Rossiia'? Svezhii vzgliad na problemu informatsionnogo obespecheniia' skandala vokrug episkopa Diomida $v$ interesakh Kremlia. 1 August.

Credo.ru. (2008c). Prokuratura Anadyria otkazala $v$ vozbuzhdenii ugolovnogo dela po faktu khishcheniia ustavnykh dokumentov Anadyrskoi i Chukotskoi eparkhii RPTs M. 29 July. 
Credoru. (2008d). Episkop Anadyrskii i Chukotskii Diomid (Dziuban): 'Tserkov' postupaet seichas kak bol'sheviki, chto i podtolknulo menia tak rezko izlozhit' svoiu pozitsiiu. Nasha Tserkov' iz dukhovnogo ucherezhdeniia prevrashchaetsia $v$ ugolovnoe. 18 July.

Credo.ru. (2008e). Nasha Tserkov' iz dukhovnogo ucherezhdeniia prevrashehaetsia $v$ ugolovnoe. 18 July.

Credo.ru. (2008f). Monitoring SMI: Osobennosti sovremennogo pravoslaviia-ot istinnoi sviatosti do partokratii televedushchii Vladimir Solov'ev: 'Pozitsiia episkopa Diomida ni vyzyvaet u menia vnutrennego protivorechiia. 22 July.

Credo.ru. (2008g). Predsedatel' Komiteta svobody sovesti sviashchenik Gleb Iakunin 'Dlia patriarkhii glavnaia vina episkopa Domida $v$ tom chto on publichno vyskazal svoiu pozitsiiu. V sluchae keleinoi razborki oni by vse 'spustili na tormozakh'. 8 July.

Credo.ru. (2008h). Dokument Obrashchenie gruppy vliiatel'nykh sviashchennikov RPTs MP $k$ Arkhireiskomu Soboru 2008, protiv 'missionperskogo obnovlenchestva'. 9 June.

Dobychin, A. (2008). Diomida khotiat upriatat' v psikhushku. segodnia.ru. http:www.segodnia.ru/print.php?s=0\&n=6329 22 July.

Dukh khristianina. (2008). "Problemy nado reshat." Interv'iu vladyki Anadyrskogo i Chukotskogo Diomida gazete, 19 June. http://www.rons.ru/ d-06-08.html 18 July.

Ezerov, A (2008). Comments. http://www.portalCredo.ru/site/?act=news\& id $=60329 \&$ topic $=562 \&$ type $=$ forum 9 February .

Galler. (2007). Comments. http://forum.ej.ru/showthread.php? $+=282154$ 19 November.

Gazeta.ru. (2007). Episkop Diomid protiv RPTs: Tserkov ispovedalas' prokurature. 25 July.

Grani.ru. (2009). Terroristam-rodnoveram prediavleny obvineniia. January.

Il'ia. (2007). Comments. http://zavtra.ru/cgi//veil//data/Zavtra/08/743/41. html 13 February.

Innokentii, P. (2008). Comments. http://www.portal-credo.ru/site/? act $=$ news\&id $=60403 \&$ topic $=562 \&$ type $=$ forum 13 February.

Islam News. (2009). Sredi arestovannyhkh terroristov lazychnikov-chinovnik Ministerstvq Sporta. 21 January.

Ivan, K. (2007). Comments. http://www.portal-credo.ru/site/?act=news\& $\mathrm{id}=54268$ \&topic $=562 \&$ type $=$ forum 18 May.

Kozhevnikova, G. (2007). Radikal'nyi natsionalizm v Rossii i protivodeistvie emu v 2006 i pervoi polovine 2007 goda. In Aleksandr Verkhovskii (Ed.), Verkhi i nizy russkogo nationalizma (pp. 38). Moscow: Sova.

Krasheninnikov, F. (2008). Posle Rossii, 22-23. http://www.zvezda.ru/prn_ 1655.html 9 March.

Lenta.ru. (2008). RPTs vystupila za vkhozhdenie Rossii v Evrosoiuz. 2 August.

Leonid, V. (2008). Comments. http://www.izestia.ru/forum/?id_ publications $=311330022$ February.

Liuger. (2008). Comments. http://zavtra.ru/egi//vere//data/zavtra/08/743/ 41.html 13 February.

Makar. (2008). Comments. http://www/apn.ru/publications/comments 19167.htm 11 February.

Maliuta. (2008). Comments. http://www.apn.ru/publications/comments 19489.html 19 March.
Mariia. (2008). Comments. http://zavtra.ru/egi//veil//data/zavtra/08/743/ 43html 14 February.

Murav'ev, Aleksei (2008). Kommentarii dnia: Ten' Gibbona nad ruinami Tsar'grada, ili provintsial'naia konspirologiia kak novoe 'kniazheskoe zertsalo'. Credo. ru, 8 February.

Navod. (2008). Comments. http://zavtra.ru/cgi/veil//data/zavtra/08/743/ 41.html 13, 14 February.

Nikolai. (2008). Comments. http://zavtra.ru/cgi//veil//data/zavtra/08/743/ 43.html 14 February.

Patriot Sibiri. (2008). Comments. http://www/apn.ru/publications/ comments19167.htm 11 February.

Petia. (2008). Comments. http://www.apn.ru/publications/comments 19048919 March.

Porudchik. (2008). Comments. http://Zavtra.ru/cgi//veil//data/zavtra/08/ 743/42.htm 15, 19 February.

Razdumyvaiushchii.(2008). Comments. Obratite vnimanie na Miniust!. http:// portal-credo.ru/site/?act=news\&id=64504\&type=forum 1 August.

Rosbalt. (2009a). Rodnovery otvergaiut obvineniia $v$ prichastnosti $k$ teraktam. 22 January.

Rosbalt. (2009b). V Moskve zaderzhano neskol'ko gruppirovok ekstremistov. 21 January.

Rosbalt. (2009c). Shevchenko: Gruppirovka neoiazychnikov delaet real'noi ugrozy natsionalizma. 21 January.

Rus. (2008). Comments. http://www.apn.ru//publications/comments 19167.html 11 February, 19 March.

Sergei, A. (2008). Comments. http://zavtra.ru/cgi//veil//data/zavtra/08/ 793/43.html BP. 11 February.

Shekhovtsov, A (2007). Religiozno-natsionalisticheskii radikalizm i politicheskii protsess. In Verkhi i nizy russkogo nationalizma. Moscow: Sova: Aleksandr Verkhovskii.

Shnirel'man, V. (2007). Tsepnoi pes': divannaia rasologiia kak zashchitnitsa 'belogo cheloveka'. In Verkhi i nizy russkogo nationalizma. Moscow: Sova: Aleksandr Verkhovskii.

Siberia v. Nato. (2008). Comments. http://www/apn.ru/publications/ comments19167.htm 11 February.

Silovik. (2008). Comments. http://zavtra.ru/egi//veil//data/zavtra/08/743/ 142.html 13 February.

Soldat Russkogo Belogo Tsaria Imperatora Evrazii. (2008). Comments. http://Zavtra.ru/cgi//veil/zavtra/08/743/43.html 19 February.

Ukolov, R. (2009). Novyi sled y dele o moskovskikh vzryvakh. Nezavisimaia Gazeta, 22 January.

Vales. (2008). Comments. http://www.apr.ru/publications/comments 19167.html 11 February.

Vermisheva, E (2007). Aleksei II otluchen ot tserkvi. Gazeta.ru, 17 July 2007.

Yuri, K. (2008). Comments. http://forum.ej.ru/showthread.php?+=282154\& page $=31$ February.

Zaritovskii, A. (2008). Bandu biriulevskikh vzryvnikov skolotila 17-i letniaia devitsa. Izvestiia.ru, 20 December.

Zheglov, A., Trifonov, V., \& Bobrova, S. (2009). Iazycheskoe vzryvoispovedanie. Kommersant, 21 January. 